\title{
ANALISIS FAKTOR-FAKTOR YANG MEMEPENGARUHI PENYISIHAN PENGHAPUSAN AKTIVA PRODUKTIF (PPAP) PADA PERBANKAN SYARIAH DI INDONESIA
}

\author{
Nita Shintya \\ Universitas Muhammadiyah Purwokerto \\ Akhmad Darmawan \\ Universitas Muhammadiyah Purwokerto
}

\begin{abstract}
Abstrak
Tujuan penelitian ini adalah untuk menganalisis faktor-faktor yang mempengaruhi Penyisihan Penghapusan Aktiva Produktif (PPAP) pada perbankan syariah di Indonesia. Variabel dependen yang digunakan dalam penelitian ini adalah penyisihan penghapusan aktiva produktif (PPAP), sedangkan variabel independen yang digunakan dalam penelitian ini adalah Total pembiayaan (TotalFinancing/TF), Risiko pembiayaan (Non Performing Financing/NPF), Profitabilitas (Earnings Before Taxes and Provisions/EBTP).

Populasi dalam penelitian ini adalah Bank Umum Syariah di Indonesia. Sampel dalam penelitian ini adalah 36 sampel yang diklasifikasikan dengan metode purposive sampling. Data penelitian yang digunakan adalah laporan keuangan triwulanan Bank Umum Syariah dari tahun 2011 hingga 2013 yang dipublikasikan di website Bank Indonesia.

Hasil penelitian ini menunjukkan bahwa total pembiayaan (TF) tidakberpengaruh positif dan signifikan terhadap PPAP ditolak. Hal ini ditunjukan dengan nilai thitung sebesar $-4,770$ lebih kecil dari ttabel 1,703. Selanjutnya resiko pembiayaan (NPF) tidakberpengaruh positif dan signifikan terhadap PPAP ditolak. Hal ini ditunjukan dengan nilai thitung sebesar 1,650 lebih kecil dari ttabel 1,703. Kemudian profitabilitas (EBTP) tidakberpengaruh negatif dan signifikan terhadap PPAP ditolak. Hal ini ditunjukan dengan nilai thitung sebesar 1,637 lebih kecil dari ttabel 1,703. Dan secara simultan Total Pembiayaan (TF), Resiko Pembiayaan (NPF), Profitabilitas (EBTP) berpengaruh signifikan terhadap PPAP diterima. Hal ini ditunjukan dengan nilai Fhitung sebesar 10,754 lebih besar dari Ftabel 2,96.
\end{abstract}

Kata Kunci: Penyisihan Penghapusan Aktiva Produktif (PPAP), Total Pembiayaan (Total Financing/ TF) , Resiko Pembiayaan (Non Performing Financing/ NPF), Profitabilitas (Earnings Before Taxes Provisions/ EBTP). 


\section{Abstract}

The research was aimed at analyzing the factors affecting allowance for uncollectible account in islamic Banks of Indonesia. Dependent variable in this research was Allowance for Uncollectible Account (PPAP), then independent variables was Total Financing (TF), Financial Risk (Non Performing Financing/NPF), Profitability (Earnings Before Taxes And Provisions/EBTP).

The population were islamic Banks of Indonesia. The samples were 36 Banks clasified by purposive sampling method. The data were the three monthly financial reports of Islamic Banks from 2011-2013 that published on Bank of Indonesia's website.

The result showed that Total Financing (TF) did not affect positively and significantly toward PPAP which was rejected. It was shown by tcount $(-4,770)$ which was smaller than ttable $(1,703)$. Then the Financial Risk (NPF) did not affect positively and significantly toward PPAP which was rejected. It was shown by tcount $(1,650)$ which was smaller than ttable $(1,703)$, Earnings Before Taxes And Provisions (EBTP) did not affect posively and significantly toward PPAP which was rejected. It was shown by tcount $(1,637)$ which was smaller than ttable $(1,703)$. TF, NPF, EBTP simultaneously affected significantly toward PPAP which was accepted. It was shown by Fcount $(10,754)$ which was bigger than Ftable (2,96).

Keywords : $\quad$ Allowance for Uncollectible Account (PPAP), then independent variables was Total Financing (TF), Financial Risk (Non Performing Financing), Profitability (Earnings Before Taxes And Provisions).

\section{PENDAHULUAN}

\section{Latar belakang}

Perkembangan perbankan Indonesia khususnya Bank Syariah telah memperlihatkan kinerja yang menggembirakan. Kinerja manajemen bank dapat dilihat salah satunya dari penyaluran pembiayaan. pembiayaan merupakan aktiva produktif yang sangat diandalkan oleh bank, karena dapat menghasilkan pendapatan terbesar. Pembiayaan perbankan merupakan bisnis yang berisiko, dimana ada kemungkinan pembiayaan yang diberikan tidak dapatdikembalikan oleh debitur yang akhirnya akan menjadi pembiayaan bermasalah atau pembiayaan macet.

Pada kondisi seperti ini umumnya debitur penerima pembiayaan bisa mengemukakan banyak alasan. Sementara itu bank sebagai penerima dana dari masyarakat harus membayar setiap rupiah yang ditempatkan bank termasuk juga harus membayar bunga simpanan. Dengan adanya risiko tersebut maka sudah seharusnya bank hanya akan memberikan pembiayaan kepada nasabah atau debitur yang dinilai layak. Oleh karena itu, bank wajib melakukan prinsip kehati-hatian dalam proses pemberian pembiayaan, karena kegiatan ini sangat mengandung risiko yang sangat besar yang dapat mempengaruhi jumlah pembiayaan, resiko pembiayaan dan profitabilitas. Bank yang pada akhirnya akan membahayakan kesehatan dan kelangsungan usaha bank yang bersangkutan. Maka dari itu bank akan mengantisipasi hal tersebut dengan membentuk Penyisihan Penghapusan Aktiva Produktif (PPAP).

Dalam kasus perbankan syariah, masih sedikit penelitian yang menguji hipotesis Penyisihan Penghapusan Aktiva Produktif meskipun bank syariah memiliki karakteristik lingkungan yang unik. Pertama, bank syariah diatur dengan prinsip-prinsip Islam (syariat) yang menggunakan mekanisme pembagian risiko di antara para investor. Kedua, regulasiyang berhubungan dengan akuntansi syariah 
tidak membatasi penggunaan dynamic provisioning, sehingga bank Islam memiliki kecenderungan untuk membentuk penyisihan kerugian untuk menyerap kerugian di masa depan.

Penelitian ini menggunakan instrumen yaitu Jumlah pembiayaan pada Total Financing (TF), Risiko pembiayaan pada Non Performing Financing (NPF), dan Profitabilitas pada Earnings Before Taxes and Provisions (EBTP) sebagai variabel independen. Berdasarkan latar belakang diatas, peneliti mengambil judul "Analisis Faktor-Faktor yang mempengaruhi Penyisihan Penghapusan Aktiva Produktif (PPAP) pada Perbankan Syariah di Indonesia"

Berdasarkan acuan penelitian yang digunakan dan uraian latar belakang masalah di atas, perumusan masalah dalam penelitian ini adalah:

1. Apakah Total Pembiayaan (Total Financing) berpengaruh positif dan signifikan terhadap Penyisihan Penghapusan Aktiva Produktif (PPAP)?

2. Apakah Risiko pembiayaan (Non performing financing) berpengaruh positif dan signifikan terhadap Penyisihan Penghapusan Aktiva Produktif (PPAP)?

3. Apakah Profitabilitas (Earnings Before Taxes and Provisions) berpengaruh negatif dan signifikan terhadap Penyisihan Penghapusan Aktiva Produktif (PPAP)?

4. Apakah faktor Total pembiayaan (Total financing), Resiko pembiayaan (Non performing financing), dan Profitabilitas (Earnings Before Taxes and Provisions) bersama-sama berpengaruh signifikan terhadap Penyisihan Penghapusan Aktiva Produktif (PPAP)?

\section{II . TINJAUAN PUSTAKA}

\section{Penyisihan Penghapusan Aktiva Produktif (PPAP)}

Penyisihan Penghapusan Aktiva Produktif (PPAP) merupakan Cadangan yang dibentuk dengan cara membebani laba rugi tahun berjalan, dengan maksud untuk menampung kerugian yang mungkin timbul sebagai akibat dan tidak diterimanya kembali sebagian atau seluruh aktiva produktif (maksimum $1,25 \%$ ATMR). Penyisihan penghapusan aktiva produktif yang dapat diperhitungkan sebagai komponen modal pelengkap adalah maksimum persentase tertentu.( Kasmir, 2003).

Penyisihan penghapusan aktiva produktif (PPAP) merupakan salah satu akun dalam perbankan yang memiliki kecenderungan manipulasi yang cukup besar. Nilai penyisihan penghapusan aktiva produktif (PPAP) mengukur tingkat efisiensi dan biaya bank dalam membentuk penyisihan penghapusan aktiva produktif (PPAP) untuk menutup kemungkinan risiko yang terjadi karena tidak tertagihnya fasilitas kredit atau bentuk investasi aktiva produktif lain. Semakin besar PPAP berarti semakin besar estimasi terhadap timbulnya pembiayaan yang bermasalah sekalipun di pihak lain hal ini mencerminkan kemampuan bank untuk menanggulangi kemungkinan tersebut.

Pada awalnya semua pembiayaan adalah pembiayaan lancar, maka PPAP dihitung sebagai persentase tertentu terhadap total pembiayaan. Kemudian kalaupembiayaan berkembang sehingga ada yang kurang lancar, maka terhadap yang kurang lancar tersebut perlu disisihkan PPAP yang lebih besar, begitu seterusnyasehingga untuk pembiayaan yang sudah digolongkan sebagai pembiayaan macet, PPAP yang disisihkan adalah sebesar 100\% dari jumlah debet yang macet (Dunil, 2005).

\section{Penentuan Penyisihan Aktiva Produktif Yang Diklasifikasikan}

Taswan (2003) Pengakuan penyisihan aktiva produktif dengan menggunakan metode cadangan akan membawa konsekuensi pada penentuan besarnya penyisihan dan cadangan yang akan disajikan dalam neraca maupun laporan L/R. Untuk menentukan besarnya cadangan, ada dua pendekatan: 


\section{Pendekatan Rugi Laba}

Dalam pendekatan ini yang di tentukan terlebih dahulu adalah besarnya penghapusan/ penyisihan penghapusan aktiva produktif yang akan disajikan dalam laporan rugi/laba, sedangkan besarnya cadangan penyisihan ditentukan kemudian. Penentuan besarnya cadangan penghapusan dapat dilakukan secara intuisi atau presentase tertentu dari debet aktiva produktif.

2. Pendekatan Neraca

Dalam pendekatan ini yang ditentukan terlebih dahulu adalah besarnya cadangan penghapusan aktiva produktif yang disajikan di neraca. Sedangkan besarnya cadangan penghapusan yang disajikan di laporan rugi/laba ditentukan kemudian.

Persoalan selanjutnya adalah menentukan tingkat PPAP yang harus dibentuk. Dalam hal ini bank wajib membentuk PPAP berupa cadangan umum dan cadangan khusus guna menutup risiko kemungkinan kerugian. Cadangan yang di bentuk dari aktiva produktif ini terdiri dari:

1. cadangan umum PPAP ditetapkan sekurang-kurangnya sebesar $1 \%$ dari aktiva produktif yang digolongkan lancar, tidak termasuk SBI dan surat utang pemerintah.

2. cadangan khusus PPAP ditetapkan sekurang-kurangnya sebesar :

1. $5 \%$ dari aktiva produktif yang digolongkan dalam perhatian khusus.

2. $15 \%$ dari aktiva produktif yang digolongkan kurang lancar setelah dikurangi nilai agunan.

3. 50\% dari aktiva produktif yang digolongkan diragukan setelah dikurangi nilai agunan, dan

4. $100 \%$ dari aktiva produktif yang digolongkan macet setelah dikurangi nilai agunan.

\section{Pembiayaan Syariah}

Dalam Islam pembiayaan dapat terjadi karena ada satu pihak memberikan dana yang memungkinkan suatu transaksi. Pihak penjual dapat memberikan pembiayaan dengan memberikan fasilitas penundaan pembayaran, sedangkan pihak pembeli dapat memberikan pembiayaan dengan memberikan fasilitas penundaan penyerahan obyek transaksi. Di samping kedua pihak tersebut, pembiayaan dapat diberikan oleh pihak lain (misalnya lembaga keuangan) untuk memfasilitasi terjadinya transaksi. Pembiayaan dapat diberikan kepada pihak penjual dengan memberikan pembayaran (sebagian atau seluruhnya) sebelum penjual dapat menyerahkan obyek transaksi, atau diberikan kepada pihak pembelidengan menyerahkan obyek transaksi sebelum pembeli dapat membayar lunas.Dalam UU no 21 tahun 2008 tentang Perbankan Syariah, Pembiayaan pada bank syariah adalah penyediaan dana atau tagihan yang berdasarkan persetujuan ataukesepakatan antara Bank Syariah dan/atau UUS dan pihak lain yang mewajibkan pihak yang dibiayai dan/atau diberi fasilitas dana untuk mengembalikan dana tersebut setelah jangka waktu tertentu dengan imbalan ujrah, tanpa imbalan, atau bagi hasil. Pembiayaan tersebut dapat berupa:

1. Transaksi bagi hasil dalam bentuk mudharabah dan musyarakah

2. Transaksi sewa-menyewa dalam bentuk ijarah atau sewa beli dalambentuk ijarah muntahiya bittamlik

3. Transaksi jual beli dalam bentuk piutang murabahah, salam, dan istishna'

4. Transaksi pinjam meminjam dalam bentuk piutang qardh; dan

5. Transaksi sewa-menyewa jasa dalam bentuk ijarah untuk transaksi multijasa.

\section{Total Pembiayaan (Total Financing/ TF)}

Adalah jumlah pembiayaan syariah terhadap dan juga merupakan proxy untuk profil jumlah pembiayaan bank. Total pembiayaan (TF) dapat menunjukkan adanya implementasi dinamic 
provisioning yang dilakukan oleh bank syariah. Total pembiayaan diharapkan akan menunjukkan pengaruh yang positif terhadap Penyisihan Penghapusan Aktiva Produktif (PPAP). Boulila dan Kilic (2010) dan Pe'rez. (2008), menjelaskan bahwa semakin besar jumlah pembiayaan yang diberikan suatu bank memiliki kecenderungan untuk mempunyai tingkat cadangan PPAP yang lebih tinggi.

$$
\text { TF = Logaritma Natural Total Pembiayaan }
$$

\section{Resiko Pembiayaan (Non performing financing INPF)}

Merupakan salah satu pengukuran dari rasio risiko usaha bank yang menunjukkan besarnya resiko pembiayaan bermasalah yang ada pada suatu bank (lqbal dan Abbas, 2007). NPF merupakan rasio yang dipergunakan untuk mengukur kemampuan bank dalam mencegah resiko kegagalan pengembalian kredit oleh debitur. NPF mencerminkan resiko pembiayaan, semakin kecil NPF semakin kecil pula resiko pembiayaan yang ditanggung pihak bank.

Bank dengan risiko pembiayaan yang tinggi akan memperbesar biaya, baik pencadangan aktiva produktif maupun biaya lainnya,sehingga berpotensi terhadap kerugian bank. Bank dalam memberikan pembiayaan harus melakukan analisis terhadap kemampuan debitur untuk membayar kembali kewajibannya. (Mawardi, 2005). Risiko pembiayaan adalah suatu risiko akibat kegagalan atau ketidakmampuan nasabah mengembalikan jumlah pinjaman dari bank beserta bunganya sesuai jangka waktu yang telah ditentukan atau dijadwalkan. Pada dasarnya, seluruh kredit memiliki risiko kredit bagi bank. Namun kredit yang memiliki risiko paling besar adalah kredit yang termasuk golongan non performing financing (NPF).

$$
\text { NPF }=\frac{\text { Total Pembiayaan Bermasalah }}{\text { Total Pembiayaan }} \times 100 \%
$$

\section{Profitabilitas diukur dengan menggunakanEBTP (Earning Before Taxes and Provisions)}

Merupakan variabel laba operasi bersih sebelum pajak dan cadangan Bank Umum Syariah pada periode triwulanan dari tahun 2011-2013, dinormalisasi dengan total aset. EBTP menunjukkan kemampuan bank menghasilkan laba dari aktivitas operasionalnya. Ketika bank syariah menerima pendapatan yang tinggi, maka bank akan cenderung meningkatkan jumlah cadangannya, demikian juga sebaliknya. EBTP merupakan perbandingan antara variabel laba operasi bersih sebelum pajak dan total asset. Menurut Tobing dan Nur (2009), jika bank memiliki kinerja yang bagus di tahun ini dan memprediksi kinerja yang tidak baik di waktu yang akan datang (good-poor), maka manajer bank akan menyimpan laba tahun ini untuk digunakan di waktu yang akan datang dengan cara mengurangi laba melalui peningkatan beban PPAP, sedangkan jika bank memiliki kinerja yang tidak baik di tahun ini dan memprediksi kinerja yang baik di waktu yang akan datang (poor-good), maka bank akan meningkatkan laba tahun ini dengan cara meminjam laba masa depan melalui penurunan beban PPAP.

$$
\text { EBTP }=\frac{\text { Lababersih sebelum pajak }}{\text { Total Asset }} \times 100 \%
$$




\section{Kerangka Pemikiran}

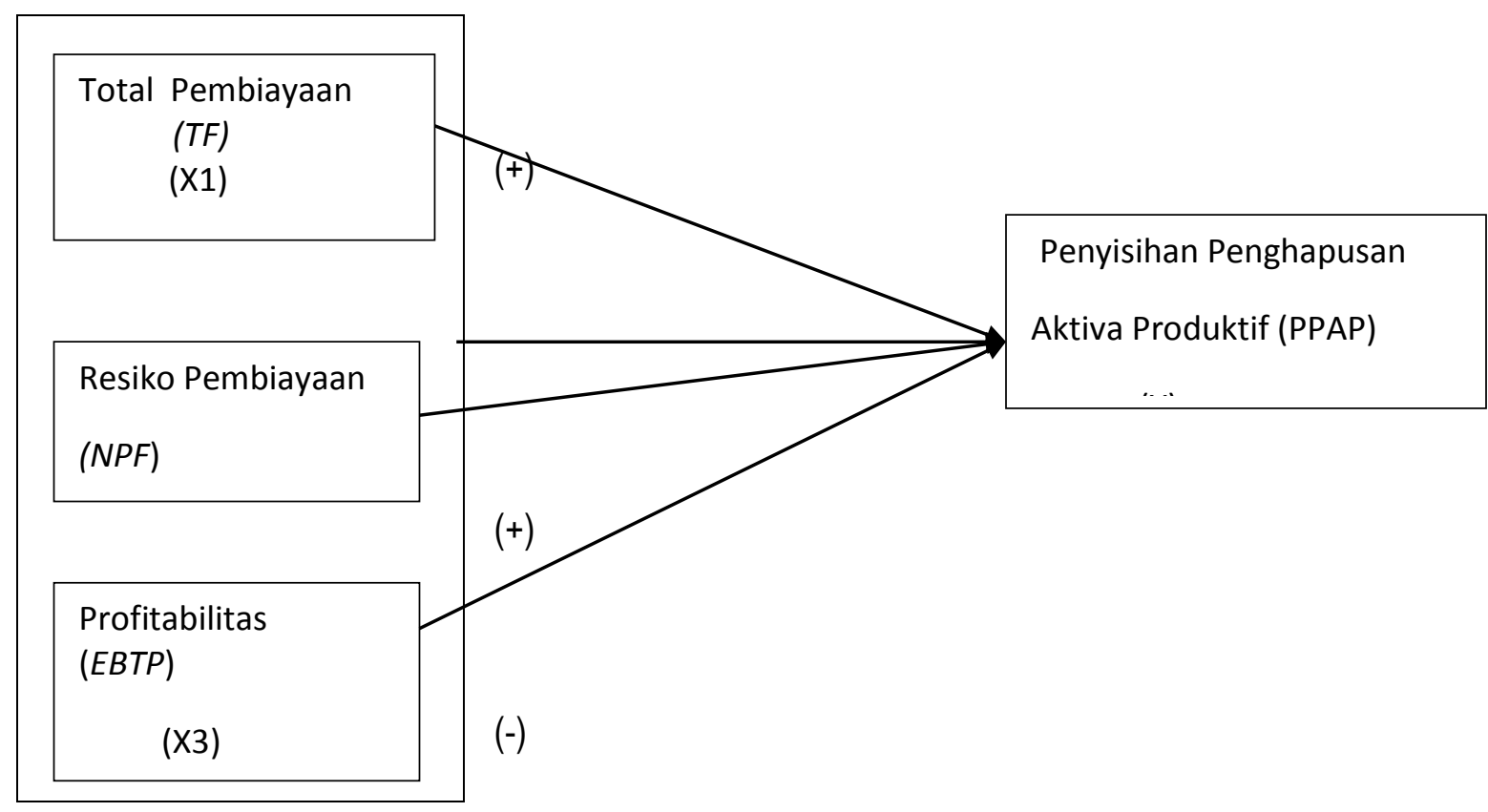

\section{Hipotesis Penelitian}

H1: Total Pembiayaan (Total Financing) berpengaruh positif dan signifikan terhadap Penyisihan Penghapusan Aktiva Produktif (PPAP).

H2: Risiko pembiayaan (Non performing financing/NPF) berpengaruh positif dan signifikan terhadap Penyisihan Penghapusan Aktiva Produktif (PPAP).

H3 : Profitabilitas (Earning Before Taxes and Provisions/EBTP) berpengaruh negatif dan signifikan terhadap Penyisihan Penghapusan Aktiva Produktif (PPAP).

H4 : Total Pembiayaan, Resiko pembiayaan, Profitabilitas bersama-sama berpengaruh siginfikan terhadap Penyisihan Penghapusan Aktiva Produktif (PPAP).

\section{III . METODE PENELITIAN}

\section{Jenis Penelitian}

Jenis penelitian yang di gunakan adalah penelitian kuantitatif yaitu penelitian biasanya dapat dijelaskan dengan angka-angka. (Burhan 2011). Dimana menggunakan data sekunder berasal dari laporan keuangan Bank Umum Syariah (BUS) triwulanan dari 2011-2013. 


\section{Data yang diperlukan}

Data yang digunakan dalam penelitian ini berasal dari laporan keuangan Bank Umum Syariah triwulanan dari tahun 2011-2013 yang dapat diakses langsung melalui situs Bank Indonesia (www.bi.go.id). Periode ini dipilih karena implementasi undang-undang bank syariah di Indonesia sesuai dengan Undang-Undang No. 21 tahun 2008 tentang perbankan syariah mulai diterapkan pada tahun 2008.

\section{Populasi dan Sampel}

Populasi adalah keseluruhan sebjek penelitian,dalam penelitian ini adalah Bank Umum Syariah (BUS). Sedangkan sampel adalah sebagian atau wakil populasi yang di teliti dalam penelitian ini yaitu seluruh Bank Umum Syariah (BUS) berupa laporan keuangan triwulanan dari tahun 2011- 2013.

\section{Definisi Operasional}

\begin{tabular}{|l|c|c|}
\hline Variabel & \multicolumn{1}{|c|}{ Indikator } & Skala \\
\hline $\begin{array}{l}\text { Penyisihan Penghapusan } \\
\text { Aktiva Produktif (PPAP) }\end{array}$ & PPAP $=\frac{\text { PPAP yang telah dibentuk }}{\text { PPAP yang wajib dibentuk }} \times 100 \%$ & Rasio \\
\hline $\begin{array}{l}\text { Total Pembiayaan (Total } \\
\text { Financing) }\end{array}$ & TF = Logaritma Natural Total Pembiayaan & Nominal \\
\hline $\begin{array}{l}\text { Risiko pembiayaan(Non } \\
\text { PerformingFinancing/NPF) }\end{array}$ & NPF $=\frac{\text { Total Pembiayaan Bermasalah }}{\text { Total Pembiayaan }} \times 100 \%$ & Rasio \\
\hline $\begin{array}{l}\text { Profitabilitas Earning } \\
\text { before Taxes and } \\
\text { Provisions(EBTP) }\end{array}$ & EBTP= $\frac{\text { Laba bersih sebelum pajak }}{\text { Total Asset }} \times 100 \%$ & Rasio \\
\hline
\end{tabular}

\section{Metode Analisis Data}

Dalam penelitian ini penulis menganalisis data dengan menggunakan teknik analisis regresi linear berganda, untuk mempermudah peneliti dalam menganalisis data serta agar hasil yang diperoleh lebih akurat dan efisien, maka perhitungannya menggunakan bantuan program komputer SPSS (Statistical Product and Service Solutions). Teknik analisis ini digunakan untuk menguji pengaruh dan hubungan beberapa variable bebas dengan variable terikat.

\section{Uji Asumsi Klasik}

a. Uji Normalitas

b. Uji Multikolinearitas

c. Uji Autokorelasi

d. Uji Heteroskedastisitas 


\section{Analisis Regresi Linear Berganda}

Analisis Regresi Linear Berganda digunakan untuk mengetahui pengaruh antara faktor Jumlah Pembiayaan, Resiko Pembiayaan, dan Profitabilitas terhadap Perataan Laba pada penggunaan PPAP. Persamaan regresi linear berganda yang di gunakan adalah ( Suharyadi,2004) :

$$
Y=a+\beta_{1} X_{1}+\beta_{2} X_{2}+\beta_{3} X_{3}+e
$$

Keterangan :

$\begin{array}{ll}\mathrm{Y} & =\text { Penyisihan Penghapusan Aktiva Produktif (PPAP) } \\ \mathrm{X}_{1} & =\text { Total Pembiayaan (TF) } \\ \mathrm{X}_{2} & =\text { Resiko Pembiayaan (NPF) } \\ \mathrm{X}_{3} & =\text { Profitabilitas (EBTP) } \\ \mathrm{a} & =\text { Nilai Konstanta } \\ \beta_{1}, \beta_{2}, \beta_{3} & =\text { Koefisien Regresi } \\ \mathrm{e} & =\text { Nilai Residual (variabel pengganggu). }\end{array}$

\section{Koefesien Determinasi $\left(\mathbf{R}^{2}\right)$}

Koefisien determinasi $\left(\mathrm{R}^{2}\right)$ pada intinya mengukur seberapa jauh model dalam menerangkan variasi variabel independen. Nilai koefisien determinasi adalah antara nol dan satu. (Ghozali, 2013).

\section{Uji Hipotesis}

\section{a. Uji T (Parsial)}

Uji T di gunakan untuk menunjukan seberapa jauh pengaruh satu variabel penjelas/independen secara individual dalam menerangkan variasi variabel dependen.

Merumuskan hipotesis :

1. Ho : b1 $\leq 0$, artinya Total Pembiayaan (TF) tidak berpengaruh positif dan signifikan terhadap Penyisihan Penghapusan Aktiva Produktif (PPAP).

Ha:b1 > 0, artinya Total Pembiayaan (TF) berpengaruh positif dan signifikan terhadap Penyisihan Penghapusan Aktiva Produktif (PPAP).

2. Ho: b2 $\leq 0$, artinya Resiko Pembiayaan (NPF) tidak berpengaruh positif dan signifikan terhadap Penyisihan Penghapusan Aktiva Produktif (PPAP).

$\mathrm{Ha}$ : b2>0, artinya Resiko Pembiayaan (NPF) berpengaruh positif dan signifikan terhadap Penyisihan Penghapusan Aktiva Produktif (PPAP). 
3. Ho : b3 $\leq 0$, artinya Profitabilitas (EBTP) tidak berpengaruh negatif dan signifikan terhadap Penyisihan Penghapusan Aktiva Produktif (PPAP)

Ha : b3 >0, artinya Profitabilitas (EBTP) berpengaruh negatif dan signifikan terhadap Penyisihan Penghapusan Aktiva Produktif (PPAP)

Untuk mengetahui apakah variabel bebas secara parsial berpengaruh secara signifikan terhadap variabel terikat digunakan Kriteria pengujiannya adalah sebagai berikut :

1. Taraf signifikan $(a=0.05)$

2. Mencari nilai t hitung digunakan rumus (Muhammad, 2011) :

$$
t_{\text {hitung }}=\frac{b i}{S b i}
$$

Keterangan :

$b=$ Koefisien Regresi

$S=$ Standar error

3. Ho diterima jika : $-t_{\text {table }} \leq t_{\text {hitung }} \leq t_{\text {table }}(n-k)$

4. HO ditolak jika : .thitung $>$ tableatau thitung $<-t_{\text {tabel }}(n-k)$

5. Kurva normal :

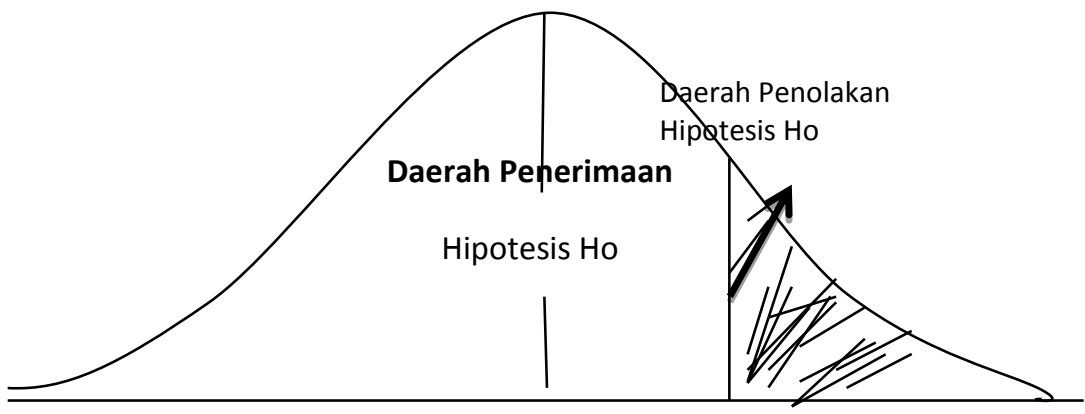

Ttabel

\section{b. Uji F (Simultan)}

Uji $F$ yaitu suatu uji untuk mengetahui pengaruh signifikan variabel bebas secara simultan atau bersama-sama terhadap variabel terikat.

Merumuskan hipotesis :

1. $\mathrm{H} 0$ : b1, b2, b3, $\leq 0$, artinya secara bersama-sama tidak ada pengaruh

signifikan dari variabel bebas, yaitu Total pembiayaan (TF) (X1), Resiko Pembiayaan (NPF) (X2), Profitabilitas (EBTP) (X3) terhadap variabel terikat yaitu Penyisihan Penghapusan Aktiva Produktif (PPAP) (Y).

2. Ha : b1, b2, b3,>0, artinya secara bersama-sama ada pengaruh

signifikan dari variabel bebas, yaitu Total Pembiayaan (TF) (X1), Resiko Pembiayaan (NPF) (X2), Profitabilitas (EBTP) (X3) terhadap variabel terikat yaitu Penyisihan Penghapusan Aktiva Produktif (PPAP) (Y). 
Untuk mengetahui apakah variabel bebas secara bersama-sama berpengaruh signifikan terhadap variabel terikat digunakan rumus (Suharyadi, 2004) :

$$
\mathrm{F}_{\text {hitung }}=\frac{\mathrm{R}^{2} / \mathrm{k}}{\left(1-\mathrm{R}^{2}\right) /(\mathrm{n}-\mathrm{k}-1)}
$$

Keterangan :

$\mathrm{R}^{2}=$ Koefisien determinasi

$\mathrm{k}=$ Jumah variabel

$\mathrm{n} \quad$ = Banyaknya sampel

$\mathrm{F}$ hitung selanjutnya dibandingkan dengan $\mathrm{F}$ tabel

Kriteria pengujiannya adalah sebagai berikut:

Membandingkan Fhitung dengan Ftabelpada $\alpha=0,05$ apabila hasil perhitungannya menunjukkan:

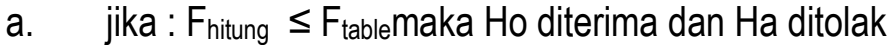

b. jika : $F_{\text {hitung }} F_{\text {tablemaka }}$ Ho ditolak dan Ha diterima.

c. Kurva normal

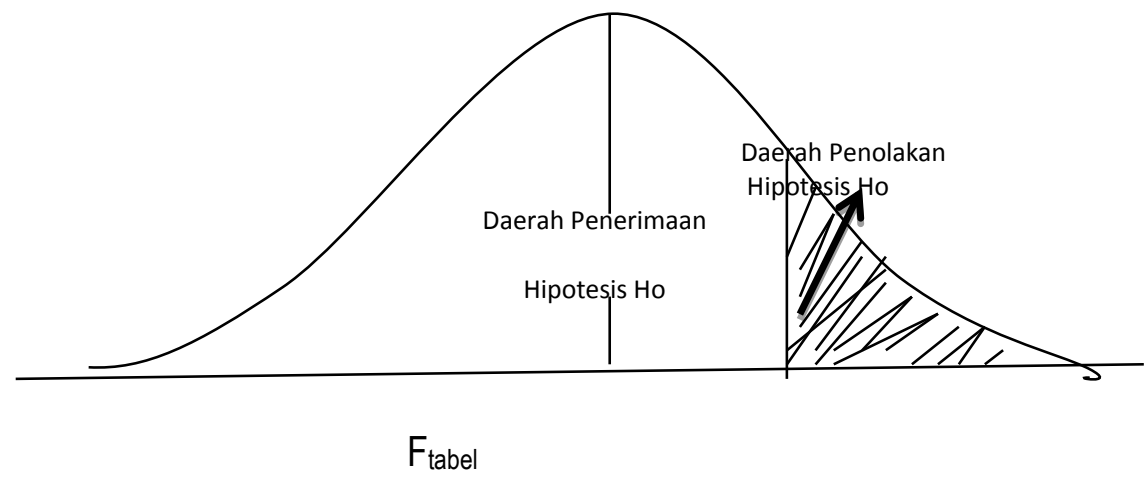

\section{HASIL DAN PEMBAHASAN}

1. Uji Asumsi Klasik

\section{a. Uji Normalitas}

Dari hasil pengujian statistik One-Sample Kolmogorov-Smirnov Test yang menunjukan nilai Asymp. Sig (2- tailed) sebesar 0,109. Terlihat bahwa nilai Asymp. Sig (2-tailed) lebih besar dari 0,05 . Dengan demikian data residual terdistribusi dapat dikatakan normal dan memenuhi syarat uji normalitas.

\section{b. Uji Multikolinearitas}

Dari hasil pengujian multikolinearitas yang dilakukan diperoleh hasil dengan nilai Tolerance untuk semua variabel independen diatas 0,10 dan nilai VIF untuk semua variabel independen juga dibawah 10. Hal ini sesuai dengan syarat tidak terjadimultikolinearitas, sehingga semua variabel independen tersebut layak digunakan sebagai variabel predictor dan tidak ada masalah dengan multikolinearitas. 


\section{c. Uji Autokorelasi}

Hasil uji Autokorelasi yang dilakukan diperoleh nilai Durbin-Watson (d) sebesar 1,928, sedangkan besarnya DW tabel untuk sampel $(n) 31$ dengan variabel independen $3(k=3)$ adalah $d l$ (batas atas) $=1,229$, du (batas bawah) $=1,650,4-d l=2,771$, dan 4-du= 2,35, sehingga dapat dinilaidu $<\mathrm{d}<4$-du adalah 1,650 $<1,928<2,35$. Hal tersebut berarti bahwa model regresi tidak ada autokorelasi positif atau negatif. Dan keputusannya tidak ditolak.

\section{d. Uji Heteroskedastisitas}

Dari hasil pengujian heterokedastistas yang dilakukan seperti yang terlihat pada tabel 4.10 , diperoleh hasil dengan nilai sig. semua variabel independen diatas 0,05 . Hal ini sesuai dengan syarat tidak terjadi heterokedastisitas, sehingga semua variabel independen layak digunakan sebagai variabel predictor dan tidak ada masalah dengan heterokedastisitas.

\section{Analisis Regresi Linear Berganda}

Berdasarkan hasil analisis linear berganda digunakan untuk mendapat koefisien regresi yang akan menentukan apakah hipotesis yang dibuat akan diterima atau ditolak.

PPAP $=1,828-0,031 \mathrm{TF}+0,008 \mathrm{NPF}+0,035 \mathrm{EBTP}$

Berdasarkan regresi tersebut diatas diketahui bahwa :

$a=1,828$ : Hal ini berarti jika variabel TF, NPF, dan EBTP bernilai nol maka nilai PPAP sebesar $1,828 \%$.

$\beta 1=-0,031$ : Variabel TF (X1) memiliki nilai koefisien regresi negatif sebesar 0,028 . Hal ini menggambarkan bahwa jika variabel TF mengalami peningkatan $1 \%$, maka akan menurunkan PPAP sebesar $0,031 \%$.

$\beta 2=0,008$ : Variabel NPF (X2) memiliki nilai koefisien regresi positif sebesar 0,001 . Hal ini menggambarkan bahwa jika variabel NPF mengalami peningkatan $1 \%$, maka akan meningkatkan PPAP sebesar 0,008\%.

$\beta 3=0,035$ : Variabel EBTP $(X 3)$ memiliki nilai koefisien regresi positif sebesar 0,035 . Hal ini menggambarkan bahwa jika variabel EBTP mengalami peningkatan $1 \%$, maka akan meningkatkan PPAP sebesar 0,035\%.

\section{Koefesien Determinasi $\left(R^{2}\right)$}

Hasil uji regresi menghasilkan bahwa koefesien determinasi menunjukan nilai Adjusted $R$-Square sebesar 0,494 artinya variabel TF, NPF, dan EBTP berpengaruh terhadap PPAP sebesar 49,4\% sedangkan sisanya sebesar 50,6\% dipengaruhi oleh faktor lain yang tidak diteliti dalam penelitian ini. 


\section{Hasil Uji Hipotesis}

\section{a. Uji t (parsial)}

Variabel total pembiayaan (TF) berpengaruh postif dan signifikan terhadap Penyisihan Penghapusan Aktiva Produktif (PPAP), diperoleh nilai thitung variabel total pembiayaan (TF) sebesar $-4,770$ sedangkan nilai ttabel sebesar 1,703. Sehingga dapat diketahui $t_{\text {hitung }} \leq t_{\text {tableyaitu }}$ $4,770 \leq 1,703$, serta nilai signifikan sebesar 0,000 lebih kecil dari 0,05 . Hal ini menunjukan bahwa total pembiayaan secara parsial berpengaruh positif dan signifikan terhadap PPAP ditolak.

Variabel resiko pembiayaan (NPF) berpengaruh posistif dan signifikan terhadap PPAP, diperoleh thitung variabel resiko pembiayaan (NPF) sebesar 1,650 sedangkan nilai ttabel sebesar 1,703. Sehingga dapat diketahui bahwa thitung $\leq$ ttabel yaitu $1,650 \leq 1703$, serta nilai signifikan sebesar 0,110 lebih besar dari 0,05 . Hal ini menunjukan resiko pembiayaan (NPF) secara parsial berpengaruh positif dan signifikan terhadap PPAP ditolak.

Variabel profitabilitas (EBTP) berpengaruh negatif dan signifikan terhadap PPAP. Diperoleh thitung variabel profitabilitas (EBTP) sebesar 1,637 sedangkan nilai ttabel sebesar 1,703 sehingga dapat diketahui bahwa thitung $\leq$ ttabel yaitu 1,637 $\leq 1,703$, serta nilai signifikan 0,113 lebih besar dari 0,05 . Hal ini menunjukan profitabilitas (EBTP) secara parsial berpengaruh negatif dan signifikan terhadap PPAP ditolak.

\section{b. Uji F (Simultan)}

Dalam penelitian ini adalah total pembiayaan (TF), resiko pembiayaan (NPF), dan profitabilitas (EBTP) secara simultan berpengaruh terhadap Penyisihan Penghapusan Aktiva Produktif (PPAP). Berdasarkan nilai Fhitung sebesar 10,754 dan Ftabel 2,96. Sehingga diketahui Fhitung> Ftabel yaitu $10,754>2,96$ serta nilai signifikansi sebesar 0,000 lebih kecil dari 0,05. Hal ini menunjukan TF, NPF, dan EBTP, secara simultan berpengaruh signifikan terhadap (PPAP) diterima.

\section{PEMBAHASAN}

\section{Pengaruh Total Pembiayaan (TF) terhadap PPAP}

Dari hasil perbandingan antara thitung dan ttabel diperoleh hasil Total Pembiayaan (TF) tidak berpengaruh positif dan signifikan terhadap PPAP. Total pembiayaan digunakan untuk dapat menunjukkan adanya implementasi dinamic provisioning yang dilakukan oleh bank syariah, dengan menggunakan Logaritma Natural total pembiayaan. Tidak ditemukannya pengaruh yang positif dan signifikan terhadap PPAP diduga disebabkan total pembiayaan yang dicapai oleh bank syariah masih belum maksimal. Jumlah pembiayaan yang merupakan komponen nondiscretionary dari objek yaitu PPAP. Pada awalnya semua pembiayaanadalah pembiayaan lancar, maka PPAP dihitung sebagai persentase tertentu terhadaptotal pembiayaan. Kemudian kalau pembiayaan berkembang sehingga ada yang kurang lancar,maka terhadap yang kurang lancar tersebut perlu disisihkan PPAP yang lebih besar, begitu seterusnya sehingga untuk pembiayaan yang sudah digolongkan sebagaipembiayaan macet, PPAP yang disisihkan adalah sebesar 100\% dari jumlah debet yang macet Jadi semakin kecil pembiayaan yang disalurkan akan semakin kecil pula PPAP yang akan dibentuk, tetapi jika semakin besar pembiayaan yang disalurkan akan semakin besar pula PPAP yang akan dibentuk. 


\section{Pengaruh Resiko Pembiayaan (NPF) terhadap PPAP}

Dari hasil perbandingan antara thitung dan ttabel diperoleh hasil Resiko Pembiayaan (NPF) tidak berpengaruh positif terhadap PPAP. NPF digunakan untuk menilai satu pengukuran dari rasio risiko usaha bank yang menunjukkan besarnya resiko pembiayaan bermasalah yang ada pada suatu bank dengan cara membagi antara total pembiayaan bermasalah dengan total pembiayaan. Terdapat pengaruh yang tidak positif dan signifikan antara NPF terhadap PPAP diduga disebabkan perolehankredit yang memiliki risiko paling besar adalah kredit yang termasuk golongan non performing financing (NPF). Sesuai dengan ketentuan Bank Indonesia, pembiayaan yang termasuk golongan non performing financing adalah pembiayaan kurang lancar, diragukan, dan macet.NPFmencerminkan resiko pembiayaan, bahwa NPF tidak berpengaruh positif dan signifikan terhadap PPAP jadi perusahaan yang memiliki jumlah kredit bermasalah yang tinggi,akan memiliki kecenderungan untuk melakukan praktik PPAP yang besar pula. Adapun standar terbaik NPF adalah kurang dari $5 \%$.

\section{Pengaruh Profitabilitas (EBTP) terhadap PPAP}

Dari hasil perbandingan anatara thitung dan ttabeldiperoleh hasil Profitabiltas (EBTP) tidakberpengaruh negatif terhadap PPAP. EBTP digunakan untuk menilai profitabilitas suatu bank dengan cara membagi laba bersih sebelum pajak dengan total asset bank. Terdapat pengaruh yang negatif terhadap PPAP. Diduga disebabkan perolehan laba yang dicapai bank syariah sudah maksimal. Hal ini ditunjukan jika ketersediaan modal berkurang bank akan mengalami kesulitan dalam menjalankan kegiatan operasinya atau penyaluran dana, padahal sumber pendapatan terbesar bank berasal dari kegiatan penyaluran dana ini. Bank juga dapat melakukan hapus tagih terhadap pembiayaan yang benar-benar sudah tidak dapat ditagih kembali. Kegiatan hapus tagih ini akan mengurangi volume PPAP dan semakin besar PPAP akan mengurangi modal karena PPAP dibentuk dari modal, bank yang mengalami kekurangan modal profitabilitasnya akan terganggu karena modal berfungsi menunjang kegiatan operasional usaha bank. Berdasar uraian tersebut dapat diambil kesimpulan bahwa profitabilitas memiliki pengaruh negatif terhadap PPAP. Jadi jika PPAP tinggi, maka keuntungan bank akan menurun, tetapi jika PPAP turun maka keuntungan bank akan naik.

\section{KESIMPULAN DAN SARAN}

\section{Kesimpulan}

Berdasarkan analisis yang telah diuraikan, maka ditarik kesimpulan anatara lain :

1. Total Pembiayaan (TF) tidak berpengaruh positif dan signifikan terhadap Penyisihan Penghapusan Aktiva Produktif (PPAP).

2. Resiko pembiayaan (NPF) tidak berpengaruh positif dan signifikan terhadap Penyisihan Penghapusan Aktiva Produktif (PPAP).

3. Profitabilitas (EBTP)tidakberpengaruh negatif dan signifikan terhadap Penyisihan Pengahapusan Aktiva Produktif (PPAP).

4. Total pembiayaan (TF), Resiko pembiayaan (NPF), dan Profitabilitas (EBTP) secara bersama-sama berpengaruh signifikan terhadap Penyisihan Pengahpusan Aktiva Produktif (PPAP).

\section{Saran}

1. Para peneliti dan akademisi

Untuk penelitian selanjutnya sebaiknya rentang waktu yang lebih panjang dan menggunakan sampel yang lebih beragam agar diperoleh hasil yang akurat serta menambah variabel lainnya seperti CAR (Capital Adequacy Ratio), FDR (Financing to Deposit Ratio). Dan diharapkan akan 
menambah wawasan dan pengetahuan yang berkaitan dengan Perbankan Syariah di Indonesia, khususnya praktik Penyisihan Penghapusan Aktiva Produktif.

2. Praktisi ekonomi dan masyarakat

Penelitian selanjutnya diharapkan dapat memberi masukan dan saran yang bermanfaat, serta dapat dijadikan bahan pertimbangan pengambilan keputusan dalam sertat ransaksi dengan bank syariah, juga kemungkinan-kemungkinan lain yang menyebabkan hasil keuangan yang stabil pada lembaga keuangan Islam.

3. Bank Indonesia dan Pemerintah

Bahwa indikasi Penyisihan Penghapusan Aktiva Produktif di perbankan syariah perlu mendapat perhatian dari $\mathrm{BI}$ dan pemerintah agar setiap bank syariah harus mewajibkan membentuk Penyisihan Penghapusan Aktiva Produktif sekurang-kurangnya $1 \%$.

\section{DAFTAR PUSTAKA}

Boulila, Taktak, Neila, Sarra Ben Slama Zouari, Abdelkader Boudriga (2010), Do Islamic Banks Use Loan Loss Provisions to Smooth Their Result?, Journal of Islamic Accounting and Business Research Vol. 1 No. 2, 2010

Bungin, Burhan. (2011). Metodologi Penelitian Kuantitatif Komunikasi, Ekonomi, dan Kebijakan Publik serta IImu-IImu Sosial Lainnya. Jakarta: Kencana.

Dunil, Z (2005), Bank Auditing Risk-Based Audit Dalam Pemeriksaan Perkreditan Bank Umum, Jakarta: PT. Indeks Kelompok Gramedia.

Firdaus, Muhammad.(2011). Ekonometrika Suatu Pendekatan Aplikatif (edisi kedua). Jember : Bumi Aksara.

Ghozali, Imam.(2013).Aplikasi Analisis Multivariate dengan Program IBM SPSS21.Semarang: Universitas Diponegoro.

Iqbal, Zamir dan Abbas Mirakhor, (2007), An Introduction to Islamic Finance Theory and Practice, Singapore : Wiley

Kasmir, (2003). Manajemen Perbankan. Jakarta: PT Raja Grafindo persada.

Kilic, Emre, Gerald J. Lobo, Tharindra Ranasinghe, K. Sivaramakrishnan (2010), The Impact of SFAS 133 on Income Smoothing by Banks through Loan Loss Provisions, http://spears.okstate.edu/accounting/files/Lobo_paper.pdf,diakses pada 20 Februari 2012

Mawardi, Wisnu (2005), Analisis Faktor-faktor Yang Mempengaruhi Kinerja Keuangan Bank Umum di Indonesia (Studi Kasus Pada Bank Umum Dengan Total Assets Kurang Dari 1 Triliun).Jurnal Bisnis Dan Strategi. Vol.14. No.1. Juli 2005.

Pe'rez, D., Salas, V. and Saurina, J. (2006), Earnings and Capital Management In Alternative Loan Loss Provision Regulatory Regimes, Banco De Espana, No. 0614

Suharyadi dan Purwanto. 2004. Statistika Untuk Ekonomi \& Keuangan Modern. Jakarta : Salemba Empat.

Taswan.(2003). Akuntansi Perbankan: Transaksi dalam Valuta Asing, Yogyakarta : UPP AMP YKPN.

Tobing, Winson R.L. dan Nur Ika Anggorowati (2009), Perataan Laba Melalui Penyisihan Penghapusan Aktiva Produktif (PPAP) Sektor Perbankan, Jurnal Akuntabilitas Vol. 9, No. 1, September 2009, h 50-62

Undang-Undang Republik Indonesia Nomor 21 Tahun 2008 tentang Perbankan Syariah. 